\title{
Overriding Mandatory Rules as a Vehicle for Weaker Party Protection in European Private International Law
}

\author{
Laura Maria van Bochove*
}

\begin{abstract}
The Rome I Regulation on the law applicable to contractual obligations contains several provisions aimed explicitly at the protection of 'weaker' contracting parties, such as consumers and employees. However, in addition to this, the interests of weaker parties are sometimes also safeguarded through the application of 'overriding mandatory provisions', which are superimposed on the law applicable to the contract to protect a fundamental interest of a Member State. This article is an attempt to clarify the extent to which the concept of overriding mandatory provisions may serve as a vehicle for weaker party protection. To do this, it examines the definition and limitations of the concept and its relation to conflict of laws rules based on the protective principle. Finally, the article seeks to establish whether the doctrine of overriding mandatory provisions remains relevant in the case of harmonisation of substantive law at the EU level, for which it will differentiate between full and minimum harmonisation.
\end{abstract}

Keywords: overriding mandatory rules, Rome I Regulation, weaker party protection, minimum harmonisation, Consumer Rights Directive

\section{Introduction}

European private international law, ${ }^{1}$ like substantive law, contains specific rules that aim to protect contracting parties that are usually considered to be the 'weaker party', such as consumers and employees. In general, protection is provided in two ways: by establishing an 'objective' rule favouring the weaker party and by restricting party autonomy. In the field of international jurisdiction, the Brussels I Regulation ${ }^{2}$ and its successor, the Brussels Ibis Regulation, ${ }^{3}$ contain special

Assistant professor in the Department of Private International and Comparative Law at the Erasmus School of Law. The author would like to thank the reviewers for their comments.

1. In this article, Private International Law is to be understood as covering conflict of laws, international jurisdiction, and recognition and enforcement.

2. Council Regulation 44/2001, OJ 2001 L 12/1.

3. Regulation $1215 / 2012$ of the European Parliament and of the Council, OJ 2012 L351/1. provisions that determine the court of the weaker party's residence or - in the case of employees - habitual workplace has jurisdiction and set limitations on free choice of forum. ${ }^{4}$ In the area of conflict of laws (hereafter COL), similar mechanisms are used: for instance, the Rome I Regulation on the law applicable to contractual obligations ${ }^{5}$ includes several COL rules referring to the law of the weaker party's habitual residence or working place, as well as provisions imposing restrictions on free choice of law. ${ }^{6}$

In addition to the special rules aimed at the protection of weaker parties, such as consumers, employees, and - to a lesser extent - passengers and insurance policyholders, the Rome I Regulation encompasses several potential vehicles for the safeguarding of these interests. These include Arts. 3(3) and 3(4), which limit free choice of law - the main cornerstone of the Rome I Regulation - for purely national and intra-EU situations in order to counteract an evasion of mandatory national or EU law, including substantive provisions based on the protective principle. Moreover, the Rome I Regulation has two general correction mechanisms that might come into play: the public policy exception and the doctrine of overriding mandatory rules. The function of the public policy exception is to negate foreign law, which is manifestly incompatible with fundamental principles of the forum. ${ }^{7}$ Overriding mandatory rules are superimposed on the law applicable to the contract to protect an interest that is regarded as fundamental by - usually - the forum state. Out of the two mechanisms, the doctrine of overriding mandatory rules appears to play a more prominent part in the protection of weaker parties. However, the nature of its exact role needs further clarification.

This article will examine to what extent the doctrine of overriding mandatory rules can serve as a vehicle for the protection of weaker parties. For this, the following issues will be addressed: the definition of the concept of

See Arts. 8-21 Brussels I Regulation and Arts. 10-23 Brussels Ibis Regulation.

5. Regulation 593/2008 of the European Parliament and of the Council, OJ 2008 L 177/6.

6. See below, Section 3.1.

7. Th.M. de Boer, 'Unwelcome Foreign Law: Public Policy and Other Means to Protect the Fundamental Values and Public Interests of the European Community', in A. Malatesta et al. (eds.), The External Dimension of EC Private International Law in Family and Succession Matters (2008) 295, at 296 
overriding mandatory rules (Section 2), its relationship with the special protective provisions of Arts. 6 and 8 Rome I (Section 3), its relationship with the 'localising rules' incorporated in European Directives (Section 4), and the extent to which the doctrine remains relevant in the case of harmonisation of substantive law at the EU level (Section 5). Finally, Section 6 provides concluding remarks.

\section{Doctrine of Overriding Mandatory Rules}

\subsection{Definition According to the Rome I Regulation}

The doctrine of overriding mandatory rules can be traced back to German jurist Friedrich Carl von Savigny (1779-1861). In the 19th century, he developed a new approach to determine the applicable law in an international situation. ${ }^{8}$ Instead of unilateral rules that determined the scope of application of a national rule but remain silent on the applicability of foreign law, he introduced multilateral COL rules. According to von Savigny, legal relationships must be allocated to a legal system, which can be the legal system of the forum country but can also be a foreign one. He established categories of legal relationships, such as obligations and property, and designed COL rules that link these categories to a particular jurisdiction through objective connecting factors, such as the location of the property or the place of performance of a contractual obligation. Though decisional harmony and neutralism were at the heart of his theory, von Savigny allowed a limited exception in favour of unilateralism, by means of the application of 'strictly positive mandatory rules' of the lex fori, but at the same time argued that this exception would eventually disappear. ${ }^{9}$

Nevertheless, together with the public policy exception, the doctrine of overriding mandatory provisions has retained its function as a general correction mechanism in contemporary European COL. In the Rome I Regulation, overriding mandatory rules are regulated in Art. 9. Contrary to Art. 7 of its predecessor, the Rome Convention, Art. 9(1) of the Rome I Regulation provides for a definition:

Overriding mandatory provisions are provisions the respect for which is regarded as crucial by a country for safeguarding its public interests, such as its political, social or economic organisation, to such an extent that they are applicable to any situation falling within their scope, irrespective of the law otherwise applicable to the contract under this Regulation.

8. F.C. von Savigny, System des heutigen römischen Rechts, Band VIII, Berlin (1849).

9. Ibid., at 36
This description aligns with the meaning given by the Court of Justice in the Arblade case. ${ }^{10}$ What becomes clear from the definition is that overriding mandatory provisions are not just mandatory provisions. Unlike 'ordinary' mandatory provisions, their application cannot be circumvented by a choice for the law of another country. In other words, these provisions are internationally binding. They are also to be distinguished from the 'provisions that cannot be derogated from by agreement', as mentioned in Arts. 3(3) and (4) as well as in $6(2)$ and $8(1)$ of the Rome I Regulation. Not only are overriding mandatory rules enforceable irrespective of a choice of law by the parties; they also supersede the law applicable on the basis of the objective COL rules of the Regulation. After all, their application is dependent solely on the question of whether or not the situation falls within the scope of the provision.

The definition given in Art. 9(1) does not resolve all uncertainties that have arisen under Art. 7 of the Rome Convention. With regard to the provision, the article states: 'the respect for which is regarded as crucial by a country for safeguarding its public interests.' This raises several questions. For instance, what is meant by 'crucial'? How should this be determined? The European legislature seems to afford a wide margin of appreciation to the courts. ${ }^{11}$ In addition, it is not entirely clear what kinds of public interests are being targeted. The article itself mentions the state's political, social, or economic organisation, but this list is not exhaustive, since the European legislature included the words 'such as'. Controversy has existed for some time regarding the matter of how 'public interest' should be interpreted. Does it exclude provisions that protect weaker parties? This issue will be discussed in Section 2.3. Another question concerns interpretation of the words 'by a country'. Does it mean that the provision in question should only aim at protecting national public interests, or can a rule protecting a European public interest, such as the free movement of goods and free and undistorted competition, also qualify as an overriding mandatory provision? ${ }^{12}$ A strong argument in favour of the latter view is that - insofar as it would be possible to distinguish between 'national' and 'European' interests - the Member States are, in any case, obliged to secure the

10. Joined Cases C-396/96 and C-376/96, Arblade [1999] ECR I, at 8453, Rec. 30. The court states: '[...] that term must be understood as applying to national provisions compliance with which has been deemed to be so crucial for the protection of the political, social or economic order in the Member State concerned as to require compliance there with by all persons present on the national territory of that Member State and all legal relationships within that State'. This decision can in its turn be viewed as an affirmation of the definition by Francescakis; see Ph. Francescakis, Répertoire de droit international 1 (1968), at 480.

11. See also J.J. Kuipers, EU Law and Private International Law. The Interrelationship in Contractual Obligations (2012), at 71.

12. Kuipers, above n. 11, at 72; Max Planck Institute for Foreign Private and Private International Law, 'Comments on the European Commission's Proposal for a Regulation of the European Parliament and the Council on the Law Applicable to Contractual Obligations (Rome I)', 71 RabelsZ 225, at 316 (2007). 
interests of the European Union as if they were their own. ${ }^{13}$

\subsection{Limitations Set by CJEU}

In Unamar v. Navigation Maritime Bulgare, ${ }^{14}$ the Court of Justice of the European Union (CJEU) laid down certain limitations with respect to the concept of overriding mandatory rules.

The facts of this case were the following. In 2005, Unamar NV, a company incorporated in Belgium, and the Bulgarian company NMB concluded a commercial agency agreement, according to which Unamar would act as an agent in relation to the operation of NMB's container liner shipping service. The one-year agreement contained a choice of law clause for Bulgarian law and an arbitration clause for the arbitration chamber of the Chamber of Commerce and Industry in Sofia (Bulgaria). The agreement was renewed annually until the end of 2008, when NMB terminated the contract. Unamar brought proceedings before the Antwerp Commercial Court and ordered compensation. NMB contested the jurisdiction of the court, since parties had included an arbitration clause in the contract. However, the Belgian court ruled that it was competent to hear the case. It also ruled that, notwithstanding the choice for Bulgarian law, Art. 27 of the Belgian law on commercial agency contracts had to be applied as an 'overriding mandatory rule'. The Antwerp Court of Appeal declared that the arbitration clause was valid and that the Antwerp court had no jurisdiction. It also ruled that the provisions of the Belgian law on commercial agency contracts could not be qualified as overriding mandatory provisions. Moreover, the Court of Appeal held that, since Bulgaria also implemented the EU Agency Directive, establishing minimum standards for the protection of agents, Unamar received sufficient protection on the basis of the chosen law, even though Bulgarian law provided less protection than Belgian law. Unamar brought an appeal in cassation, and the Court of Cassation requested a preliminary ruling by the CJEU, asking whether the Belgian provisions exceeding the scope and the level of protection of the Agency Directive could be applied as overriding mandatory provisions of the lex fori within the meaning of Art. 7(2) of the Rome Convention, even if the law applicable to the contract was the law of an EU Member State in which the minimum protection provided by the Agency Directive had been implemented. ${ }^{15}$

In order to answer the question referred to by the Belgian Court of Cassation, the CJEU had to give its opinion on the concept of overriding mandatory rules. It makes reference to the Arblade case and Art. 9(1) of the

13. See de Boer (2008), above n. 7, at 316; R. Plender and M. Wilderspin, Private International Law on Obligations (2009), at 357.

14. Case C184/12 (not yet published in ECR).

15. Ibid., Rec. 26.
Rome I Regulation, even though this Regulation is temporally not applicable to the dispute. In addition, the CJEU imposes two restrictions with regard to giving effect to overriding mandatory rules. The first one is based on the provisions of the EU Treaty, in particular the four freedoms. According to the CJEU, the application of national rules shall not be detrimental to the primacy and uniform application of EU law. ${ }^{16}$

The second restriction is to be found in Recital 49 of the judgement, in which the CJEU states that, in order to secure the effect of the fundamental principle of freedom of contract, the term 'overriding mandatory provisions' should be interpreted strictly. Here, the CJEU pays explicit attention to the relationship between overriding mandatory provisions and party autonomy, the latter being the cornerstone of the Rome Convention and Rome I Regulation. It refuses, however, to draw radical conclusions. It follows from the judgement in Unamar that the national legislatures and courts still have a relatively large margin of appreciation and can even designate a mandatory rule as being 'overriding' if that rule is based on a minimum harmonisation Directive but exceeds the protection required by the Directive. ${ }^{17}$ This issue will be considered in more detail in Section 5.

\subsection{Public Interest in Protecting Individuals}

According to Art. 9(1), respect for overriding mandatory rules should be considered crucial by a state for 'safeguarding its public interests'. Does this imply that rules aiming at the protection of individual interests cannot be regarded as overriding mandatory provisions? The legislative history of the Rome I Regulation provides no clarity on this matter. ${ }^{18}$ According to the German Supreme Court ${ }^{19}$ and to the majority opinion in the German literature, the answer is affirmative. ${ }^{20}$ In order to qualify as an overriding mandatory provision, a rule should at least partly pursue a state interest, and the protection of this state interest should not simply be

16. Ibid., Rec. 46. See more details regarding the limitations that EU primary law imposes on the application of overriding mandatory rules; J. Fetsch, Eingriffsnormen und EG-Vertrag (2002), at $126 \mathrm{ff}$. In the German literature, it has been argued that application of the overriding mandatory rules should not only be in conformity with the four freedoms, but should also comply with the Charter of Fundamental Rights of the European Union. Lüttringhaus claims that in respect of Art. 9(1) of the Rome I Regulation, Art. 16 of the Charter - the freedom to conduct a business - is particularly relevant, since this provision encompasses freedom of contract; see J.D. Lüttringhaus, 'Eingriffsnormen in internationalen Unionsprivat- und Prozessrecht: Von Ingmar zu Unamar', IPRax 146, at 149 (2014). Although this freedom is not absolute and can be restricted, these restrictions should not be disproportionate in the sense that they affect its essence; see Case C-426/11, Alemo-Herron v. Parkwood (not yet published in ECR), Rec. 35.

17. Unamar, above n. 14, Rec. 50.

18. It should be noted that the Giuliano/Lagarde report on the Rome Convention (OJ 1980 C 282/28) does mention rules on consumer protection as an example of overriding mandatory rules.

19. Bundesgerichtshof 13 December 2005 (Case I ZR 82/05)

20. D. Martiny, 'Art. 9', Münchener Kommentar zum Bürgerliches Gesetzbuch, Band 10 - VO (EG) 593/2008, at 13 (2010); P. Hauser, Eingriffsnormen in der Rom I-Verordnung (2012), at 9-10; A. Köhler, Eingriffsnorme - Der 'Unfertige Teil' des europäischen IPR (2013), at 23. 
ancillary to the purpose of protection of an individual interest. ${ }^{21}$ With regard to consumer protection rules, from the German Supreme Court's case law, it follows that the special rule for consumer contracts in Art. 6 of the Rome I Regulation is given precedence over Art. 9. ${ }^{22}$ However, in other countries, such as the United Kingdom and France, it is thought that provisions aimed at protecting individual interests, such as consumers or employees, can be regarded as overriding mandatory rules. ${ }^{23}$ Although these provisions do not serve a specific public interest, it is reasoned that a Member State can nevertheless have an interest in applying provisions based on public policy considerations, since the abuse of weaker parties can be viewed as a threat for civil society. ${ }^{24}$ For this reason, the application of the rule itself is of public interest. ${ }^{25}$ Examples of these 'secondary generation' or 'semi-public' overriding mandatory provisions are in Section 27(2) of the English Unfair Contract Terms Act ${ }^{26}$ and in certain articles of the French loi sur le crédit à la consommation. ${ }^{27}$

In the Netherlands, according to the majority opinion in the literature, provisions aimed primarily at the protection of weaker parties can be applied as overriding mandatory rules. ${ }^{28}$ Moreover, the purpose of a rule can change over time. This is true of Art. 6 of the Dutch Labour Relations Decree (Buitengemoon Besluit Arbeidsverhoudingen), established in 1945, and with the primary goal of protecting the interests of the Dutch labour market. In Nuon v. Olbrych, ${ }^{29}$ the Dutch Supreme Court ruled that currently the protection of the employee against wrongful dismissal is given prominence. In previous case law, the key question was whether at the time of dismissal it was foreseeable that the employee would fall back on the Dutch labour market. However, in this case the Supreme Court stated that the applicability of the provision depended on whether the situation of this employee could be distinguished sufficiently from the situations of other employees working in the Netherlands and who were undoubtedly entitled to protection. Until now, the CJEU has not addressed explicitly the issue as to whether the application of a rule based on the protective principle can be regarded as crucial by a state for the safeguarding of its public interest in the sense of Art. 7 Rome Convention/Art. 9 Rome I. In Unamar, the CJEU does not distinguish between 'private' and 'public interests' but speaks about 'an interest judged to be essential by the Member State concerned' ${ }^{30}$ Since the request of the Belgian court for a preliminary ruling in this case did not address the question of whether

21. Kuipers, above n. 11, at 145.

22. See Bundesgerichtshof 19 March 1997 (Case VIII ZR 316/96).

23. For a detailed analysis, see Kuipers, above n. 11, at 125-33 (France) and 161-68 (United Kingdom).

24. L. Strikwerda, Inleiding tot het Nederlandse Internationaal Privaatrecht (2012), at 67.

25. See Hauser, above n. 20, at 9-11

26. See P. Stone, EU Private International Law (2010), at 343.

27. Cour de Cassation 19 October 1999, Bull. 281, at 183

28. See, with references, Kuipers, above n. 11, at 154.

29. Hoge Raad 24 February 2012, Nederlandse Jurisprudentie 2012/274.

30. Unamar, above n. 14, Rec. 50. rules based on the protective principle fall within the scope of Art. 9 Rome I, one could argue that the CJEU was not given the opportunity to clarify this issue. ${ }^{31}$

In my opinion, however, in Unamar the Court at least confirmed implicitly that a rule aimed primarily at the protection of a weaker party could be viewed as an overriding mandatory rule. ${ }^{32}$ Considerations based on the importance of the Agency Directive for the proper functioning of the internal market, which was emphasised by the Court in its Ingmar v. Eaton decision, ${ }^{33}$ were not applicable in the Unamar case, since the lex causae was the law of a Member State, which had correctly transposed the Agency Directive. Still, the CJEU allows a court of a Member State to apply its own national provisions pursuant to Art. 7 of the Rome Convention, which are based on the Directive but offer greater protection to commercial agents, on the condition that the legislature adopted this provision to protect a fundamental interest. ${ }^{34}$ It is difficult to imagine that the Court could reach the same conclusion and simultaneously reject the idea that national provisions based on the protective principle and not aimed explicitly at the protection of a state interest could be qualified as overriding mandatory rules. Finally, it should be recalled that the European legislature incorporated consumer protection in the Charter of Fundamental Rights ${ }^{35}$ and that the CJEU had already acknowledged that consumer protection, as well as the social protection of workers, involved a public interest. ${ }^{36}$

\subsection{Origin of the Overriding Mandatory Rule}

In keeping with Art. 7 of its predecessor, the Rome Convention, Art. 9 of the Rome I Regulation distinguishes between overriding mandatory rules of the law of the forum and of a third country. Art. 7(2) states that the Regulation does not restrict the application of overriding mandatory rules of the lex fori. In contrast, Art. 7(3) determines that the application of overriding mandatory provisions of a third country is narrowed down to situations in which the provision belongs to the law of the country of performance of the contractual obligation, and the provision renders the performance of the contract unlawful. The application of overriding mandatory rules of a third country was one of the most controversial issues under the Rome Convention and in the negotiations on Rome I. ${ }^{37}$ However, given the relative unimportance of these overriding mandatory rules

31. J.J. Kuipers and J. Vlek, 'Het Hof van Justitie en de bescherming van de handelsagent: Over voorrangsregels, dwingende bepalingen en openbare orde', Nederlands Internationaal Privaatrecht 198, at 203 (2014)

32. Lüttringhaus, above n. 16, at 148.

33. Case C-381/98 [2000] ECR I, at 9305, Rec. 24. See also below, Section 4.2 .

34. Unamar, above n. 14, Rec. 50

35. OJ 2010 C 83/389. Art. 38 reads: 'Union policies shall ensure a high level of consumer protection.'

36. See Plender and Wilderspin, above n. 13, at 339-40.

37. For an in-depth analysis, see Kuipers, above n. 11, at 78-92. Especially in the German literature, the topic is met by great interest, see, amongst others, L. Günther, Die Anwendbarkeit ausländischer Eingriffsnormen im Lichte der Rom I- und Rom II-Verordnungen (2011); Hauser, above n. 20 , at $168-320$. 
in practice, ${ }^{38}$ this issue will not be part of the following analysis.

Art. 9 of the Rome I Regulation pays no attention to overriding mandatory rules of the lex causae. ${ }^{39}$ Some commentators argue that these provisions should be applied in any case, since there are no objections arising from the principles of party autonomy and legal certainty. ${ }^{40}$ According to Bisping, 'every overriding mandatory provision is also a (simple) mandatory provision'. ${ }^{41}$ This view, however, conflicts with the fact that overriding mandatory provisions determine their own application. This means that they can be considered not only applicable irrespective of the law applicable to the contract but also inapplicable. An example of this can be found in the aforementioned Nuon/Olbrych case, in which the Dutch Supreme Court ruled that a choice of law clause in an employment agreement for Dutch law does not automatically lead to the application of Art. 6 of the Dutch Labour Relations Decree. ${ }^{42}$ This means that a court has to refuse the application of an overriding mandatory rule if the rule itself does not require application, even if it belongs to both the lex causae and the lex fori.

\section{Relation to Special COL Rules}

\subsection{Protective Provisions for Consumers and Employees}

Even if one interprets the Unamar judgement as recognition by the CJEU that national rules based on the protective principle can be qualified as overriding mandatory provisions, this does not necessarily imply that the same is true of rules aimed at protecting consumers or employees. Unlike for agency contracts, the Rome I Regulation contains special protective COL rules for consumer contracts and employment contracts. Art. 6(1) contains the objective COL rule for consumer contracts and connects to the law of the country where the consumer has his habitual residence. However, in line with Art. 15 of the Brussels I Regulation and with Art. 17 of the Brussels Ibis Regulation, the Rome I Regulation adopts a narrow definition of the concept of 'consumer'. Art. 6(1) lays down a list of requirements.

38. See C. Bisping, 'Consumer Protection and Overriding Mandatory Rules in the Rome I Regulation', European Consumer Protection: Theory and Practice (2012) 239, at 244; A.A.H. van Hoek, Internationale mobiliteit van werknemers: Een onderzoek naar de interactie tussen arbeidsrecht, EG-recht, en IPR aan de hand van de detacheringsrichtlijn (2000), at 80.

39. See W.H. Roth, 'Savigny, Eingriffsnormen und die Rom I-Verordnung', Festschrift für Gunther Kühne zum 70. Geburtstag (2009) 859, at 870; O. Remien, 'Variationen zum Thema Eingriffsnormen nach Art. 9 Rom I-VO und Art. 16 Rom II-VO unter Berücksichtigung neuerer Rechtsprechung zu Art. 7 Römer Übereinkommen', Grenzen überwinden, Prinzipien bewahren: Festschrift für Bernd von Hoffmann zum 70. Geburtstag am 28. Dezember 2011 (2011) 335, at 341.

40. Kuipers, above n. 11, at 79.

41. Bisping, above n. 38, at 252

42. Nuon, above n. 29
The contract has to be concluded by a natural person for a purpose of private use (the consumer) with a professional that should pursue his commercial or professional activities in the country where the consumer has his habitual residence or, by any means, direct such activities to the country where the consumer has his habitual residence, or several countries, including the country of the consumer's seat. Consequently, for the purposes of Art. 6(1), 'mobile' consumers, who move across borders on their own initiative and conclude a contract with a professional seated abroad that does not pursue any activities in or directs activities to the country of the consumer, are not protected. Furthermore, Art. 6(1) determines that the contract should fall within the scope of the commercial or professional activities. However, with regard to Art. 15(1)(c) of the Brussels I Regulation, which contains the same phrase, the CJEU has ruled that a causal link between the means used to direct the commercial or professional activity to the Member State of the consumer's domicile is not required. ${ }^{43}$ Art. 6(4) lists several contracts that can fall within the scope of paragraph (1) but for which the special protective rules of Arts. 6(1) and 6(2) do not apply, such as contracts relating to a right in rem in immovable property and to contracts of carriage (except for package travel contracts). For most consumer contracts falling outside the scope of Art. 6, the applicable law has to be determined on the grounds that the general objective COL rule of Art. 4 applies. ${ }^{44}$ This means that - in the absence of a choice of law - the law applicable to the contract is typically the law of the country where the seller or the service provider has his habitual residence. ${ }^{45}$

Art. 8(2) provides the objective COL rule for individual employment contracts, stating that the contract shall be governed by the law of the country in which or from which the employee habitually carries or carried out his work. To identify this place, the whole duration of the employment relationship should be taken into account. $^{46}$ If it is not possible to determine the place where the employee habitually works, the contract shall be governed by the law of the country of the place of business through which the employee was engaged (Art. 8[3]). In contrast to Art. 6, Art. 8(4) contains an escape clause for the law of the country that has a clos$\mathrm{er}^{47}$ connection with the contract.

In addition to an objective COL rule favouring the weaker party, Arts. 6(2) and 8(1) provide protection by narrowing down the free choice of law. Both provisions permit a choice of law in accordance with the general requirements incorporated in Art. 3 of the Regulation. However, they also determine that the chosen law will

43. Case C-218/12, Lokman Emrek v. Vlado Sabranovic (not yet published in ECR).

44. For contracts of carriage, the special rule of Art. 5 applies

45. See Art. 4(1) and (2). However, if the contract is manifestly more closely connected to the law of another country, the law of that other country will apply; see Art. 4(3)

46. Case C-37/00, Herbert Weber v. Universal Ogden Services Ltd., [2002] ECR I, at 2013.

47. Unlike Art. 4(5), it does not require a 'manifestly closer connection'. 
not apply insofar as it grants the consumer/employee less protection than the mandatory rules of the law applicable under the objective COL rule. Consequently, a choice of law will not deprive the consumer/employee of the protection he receives on the basis of the mandatory provisions of the law of the country where he has his habitual residence/habitually carries out his work. How should one interpret these provisions? It could be argued that they result in a 'purely substantive choice of law', without resorting to COL rules. The chosen law will then only displace the default rules that would otherwise apply. However, a more obvious interpretation - which also reflects the majority opinion in the literature - is that a national court should apply the law that offers the highest level of protection to the consumer or employee, irrespective of whether that is the chosen law or the law that applies according to the objective COL rule. $^{48}$ The consequence of this interpretation, which is called the 'preferential law' approach, ${ }^{49}$ is that the court will have to identify the mandatory provisions that offer protection of the law of the consumer's habitual residence/place where the employee habitually carries out his work and compare those to the provisions of the chosen law. Therefore, this approach is more labour intensive than the 'substantive choice of law' approach. ${ }^{50}$ At the same time, it provides the weaker party to the contract with the highest level of protection. ${ }^{51}$ While the preferential law approach does not deprive the parties of the opportunity to choose the applicable law altogether, ${ }^{52}$ it does give the stronger party an incentive not to include a choice of law clause in the contract. ${ }^{53}$ As a result, this approach manages to find a balance between party autonomy on the one hand and weaker party protection on the other.

48. F. Ragno, 'The Law Applicable to Consumer Contracts under the Rome I Regulation', in F. Ferrari and S. Leible (eds.), Rome I Regulation: The Law Applicable to Contractual Obligations in Europe (2009) 129, at 152; P. Mankowski, 'Employment Contracts under Article 8 of the Rome I Regulation', in F. Ferrari and S. Leible (eds.), Rome I Regulation: The Law Applicable to Contractual Obligations in Europe (2009) 171, at 211 .

49. G. Rühl, 'Consumer Protection in Choice of Law', 44 Cornell International Law Journal 570, at 591 (2011).

50. J. Hill, 'Article 6 of the Rome I Regulation: Much Ado About Nothing', Nederlands Internationaal Privaatrecht 437, at 443 (2009).

51. However, Kuipers doubts whether this is in conformity with the rationale behind Art. 6(2). He argues that the objective of this provision is to protect the consumer from the negative effects of a choice of law; however, the article is not aimed at increasing the level of consumer protection. An alternative option would be for the professional party to be given the opportunity to annul the choice of law and opt for applying the law of the consumer's habitual residence; see Kuipers, above n. 11, at 104

52. In the Rome I proposal, party autonomy for consumer contracts was eliminated for efficiency reasons; see COM (2005) 650, at 6-7 and O. Lando and P.A. Nielsen, 'The Rome I Proposal', Journal of Private International Law 29, at 39-40 (2007). This proposed solution was, however, subject to heavy criticism and was therefore not included in the final Regulation.

53. Mankowski, above n. 48 , at 212

\subsection{Residual Role of Overriding Mandatory Rules}

Some commentators claim that Arts. 6(2) and 9(2) of the Rome I Regulation deal with rules of the same genus and that Art. 6(2) - as the lex specialis - must be given precedence, leaving no room to invoke Art. 9 for the application of provisions whose aim is to protect the consumer. ${ }^{54}$ After all, the European legislature did choose explicitly not to grant special protection to mobile consumers, to avoid the risk of 'unfair surprise' to the seller, ${ }^{55}$ and not to overly restrict party autonomy. However, one could claim that rules that fall outside the scope of Arts. 6 and 8 can still be enforced through the safety valve offered by Art. 9. For instance, Art. 6:247 of the Dutch Civil Code requires that the Dutch provisions regarding unfair contract terms be applied irrespective of the lex causae if the consumer has his habitual residence in the Netherlands. Supposing that the Dutch legislature had qualified these protective rules as overriding mandatory rules, ${ }^{56}$ this would mean that a Dutch court could apply these provisions irrespective of a choice of law for the law of another state, even if the agreement had not been concluded under the circumstances specified in Art. 6(1) or belonged to the contracts specified in Art. 6(4). This way, Art. 9 would continue to play a role, be it more residual. ${ }^{57}$ In my opinion, a mobile consumer, who does not already receive protection on the basis of Art. 6, should at least enjoy the protection offered by Art. 9 if the state in question has a fundamental interest in the application of the protective rule. This thought is also in line with the Rome I Green Paper, which states that the special provision regarding consumer contracts 'does not interfere with the possible application of overriding mandatory rules', ${ }^{58}$ since they are a different matter. ${ }^{59}$

However, if the consumer already receives protection on the basis of Art. 6, Art. 9(2) will not apply. Suppose that the consumer has his habitual residence in Member State A, and the contract does not include a choice of law. Pursuant to Art. 6(1), the law of Member State A will be applied to the contract. If the suit is brought before the courts of Member State B and the law of Member State B provides a higher level of protection than the law of Member State A, a possible conflict between Arts. 6 and 9(2) arises. However, it is unlikely that the court of Member State B would want to apply the consumer protection provisions of the lex fori as overriding mandatory provisions, since the consumer does not have his habitual residence in this Member State. Member State B will not have an essential interest

54. See Bisping, above n. 38, at 252; Stone, above n. 26, at 354; Köhler, above n. 20, at 143

55. See Stone, above n. 26, at 352

56. See M.V. Polak in his case note on Hoge Raad 24 February 2012, Nederlandse Jurisprudentie 2012/274.

57. Kuipers, above n. 11, at 106

58. Green Paper, $\operatorname{COM}(2002) 654$ final, at 34.

59. See also Plender and Wilderspin, above n. 13, at 354. They also point to the fact that the opening words of Art. 9(2), 'Nothing in this Regulation shall restrict...', do not suggest this article is subordinate to Arts. 6 and 8. 
in protecting consumers that reside outside its territory. This has also been confirmed by the Court of Justice in Alpine Investments v. Ministerie van Financiën. ${ }^{60}$

\section{Relation to Localising Rules in Directives}

\subsection{The Concept of Localising Rules}

The Greek-American scholar Symeon Symeonides distinguishes between four types of rules designed to protect the forum state's interests and values: 1) localising rules, which are contained in substantive statutes and expressly demarcate the spatial scope of a specific statute; 2) overriding mandatory rules, which do not expressly delineate the spatial reach of a statute but have the same effect as localising rules; 3) unilateral COL rules in PIL codifications; and 4) multilateral rules designed to result in the application of the lex fori. ${ }^{61}$ The rules belonging to the first three categories are examples of real unilateralism, since they lead to the application of the lex fori and exclude foreign law. The main difference between the first and second category is that localising rules expressly determine the applicability of a statute in an international situation and displace a COL rule 'without the need to determine whether the provision reflects an important public interest'. ${ }^{62} \mathrm{Nev}-$ ertheless, in order for the provision to qualify as an overriding mandatory rule, the forum should establish whether it embodies an important public interest. ${ }^{63}$ Symeonides defines localising rules as being more specific and therefore overriding the COL rules. ${ }^{64}$

Localising rules can be found in several European Directives that aim to protect weaker parties, such as the one on distance contracting, which declares: 'Member States shall take the measures needed to ensure that the consumer does not lose the protection granted by this Directive, by virtue of the choice of the law of a nonmember country as the law applicable to the contract if the latter has close connection with the territory of one

60. Case C-384/93 [1995] ECR I, at 1141. In Rec. 43, the Court of Justice states that 'the protection of consumers in the other Member States is not, as such, a matter for the Netherlands authorities'. Kuipers, above $\mathrm{n}$. 11 , at 108 , points out that, although a Member State may have no interest in the protection of foreign consumers, this does not rule out the possibility that it has another interest in the application of the same provision, such as safeguarding the integrity of its financial market.

61. S.C. Symeonides, Codifying Choice of Law Around the World (2014), at 294.

62. Ibid., at 300

63. Ibid., at 300

64. Ibid., at 295 or more Member States' ${ }^{65}$ Another example is Art. 3(1) of the Posted Workers Directive, ${ }^{66}$ which states that the Member States have to ensure the protection of posted workers in their territory, irrespective of the law applicable to the employment relationship. The level of protection provided by these Directives therefore is guaranteed and does not depend on the COL rules of the Rome I Regulation, including Art. 9 Rome I. ${ }^{67}$ The localising rules in the Directives are usually viewed as 'provisions of Community law which, in relation to particular matters, lay down COL rules relating to contractual obligations' in the sense of Art. 23 of the Rome I Regulation, which states that these provisions prevail over the Regulation. ${ }^{68}$

However, Recital 58 of the new Consumer Rights Directive $^{69}$ provides that if the law applicable to the consumer contract is that of a third country, the Rome I Regulation should be applied to determine whether the consumer enjoys protection on the basis of the Directive. Hence, unlike many of the 'old style' consumerrelated Directives, the Consumer Rights Directive does not include a localising rule, and therefore Art. 23 of the Rome I Regulation does not come into play. Nevertheless, it remains unclear as to whether application via Art. 9 Rome I has been made completely impossible. Does the fact that the Consumer Rights Directive refers the matter to Rome I imply that a Member State cannot determine that a national provision transposing the Directive protects an interest fundamental to the Member State concerned? The CJEU will have the last word in this, but bearing in mind the discretionary leeway for

65. See Art. 12(2) of Directive 97/7/EC, OJ 1997 L 144/19. Another example of a localising rule is Art. 12(2) of Directive 2008/122/EC, OJ 2009 L33/10 (Timeshare Directive), which reads: 'Where the applicable law is that of a third country, consumers shall not be deprived of the protection granted by this Directive, as implemented in the Member State of the forum if: any of the immovable properties concerned is situated within the territory of a Member State, or, in the case of a contract not directly related to immovable property, the trader pursues commercial or professional activities in a Member State or, by any means, directs such activities to a Member State and the contract falls within the scope of such activities.' Contra: Kuipers, above n. 11, at 212, who argues that the Timeshare Directive confirms the central role of the Rome I Regulation

66. Directive 96/71/EC, OJ 1997 L 18/1

67. Recital 34 of the Rome I Regulation states that Art. 8 of the Regulation should not prejudice the application of the overriding mandatory provisions of the country to which a worker is posted in accordance with the Posted Workers Directive. However, in my opinion, Art. 3(1) of that Directive should be seen as a localising rule, and should be considered in the context of Art. 23 and not of Art. 9. See also Plender and Wilderspin, above n. 13, at 331, who argue that 'the Directive lays down an entirely separate and supplementary conflict rule for the benefit of the employee'. This is also in line with the Commission's proposal for Rome I, which mentioned this Directive as an instrument containing a COL rule within the meaning of what is now Art. 23; see COM2005(650) final, at 23. Kuipers, above n. 11, at 237-38, however, argues that the applicability of the provisions of the Posted Workers Directive should be decided on the basis of Art. 9 Rome I.

68. Stone, above n. 26, at 293-94; Ragno, above n. 48, at 159.

69. Directive 2011/83/EU, OJ 2011 L 304/64. This one replaces Directive $97 / 7 /$ EC on distance contracting as well as Directive $85 / 577 /$ EEC on doorstep selling; in addition, it amends Directive 1999/44/EC on consumer sales and guarantees, and Directive 93/13/EEC on unfair terms in consumer contracts. 
the Member States, it cannot be ruled out that the answer will be in the negative.

\subsection{Agency Directive: Overriding Mandatory Rules or Localising Rule?}

In Ingmar v. Eaton ${ }^{70}$ the question arose as to whether the English court should apply its national law based on the European Agency Directive in an international case if the agent was active in the United Kingdom, irrespective of a choice of law clause for Californian law and of the fact that the principal was established in California. According to the Court of Justice, Arts. 17 and 18 of the Directive, as implemented in English law, have a mandatory nature. ${ }^{71}$ The Court explains that the purpose of the provisions is 'to protect, for all commercial agents, freedom of establishment and the operation of undistorted competition in the internal market' ${ }^{72}$ For this reason, parties cannot deviate from these provisions by including a choice of law clause in the agency contract. ${ }^{73}$ The Ingmar case was not decided on the basis of the Rome Convention, since at that time the Court of Justice did not have the competence to interpret the provisions of this convention. Moreover, at the time of the contract's conclusion, the United Kingdom was not a party to this convention. Hence, it was unclear how this ruling should be interpreted in the light of the convention and its successor, the Rome I Regulation. Did the Court of Justice establish an independent principle for application of the Agency Directive? ${ }^{74}$ Did the Court mean to qualify the mentioned provisions of the Directive as 'overriding mandatory rules' in the sense of Art. 7 of the Rome Convention and Art. 9 of the Rome I Regulation? Should an agency contract be regarded as an employment contract, and do the protective COL rules for employment contracts apply equally? ${ }^{75}$ Or does the wording of Art. 3(4) of the Rome I Regulation - determining that in situations where all relevant elements are located on EU territory, a choice of law for the law of a non-Member State shall not prejudice the application of mandatory EU rules - imply that Ingmar, in which there was a connection with a third country, is no longer valid? ${ }^{76}$

In Unamar, the CJEU has clarified that the question of whether a national court may reject the application of the chosen law in favour of national law transposing Arts. 17 and 18 of the Agency Directive should be considered in the context of Art. 7 of the Rome Conven-

70. See above, n. 33

71. Ibid., Rec. 22.

72. Ibid., Rec. 24.

73. Ibid., Rec. 26.

74. See H. Heiss, 'Party Autonomy', in F. Ferrari and S. Leible (eds.), Rome I Regulation: The Law Applicable to Contractual Obligations in Europe (2009) 1, at 8.

75. Unamar, above n. 14, Rec. 41

76. See Plender and Wilderspin, above n. 13, at 163-64. The legislative history of Art. 3(4) of Rome I shows that the Commission Proposal COM (2005) 650 final did not restrict the application of EU mandatory law to purely EU cases. Art. 3(5) of the Proposal stated: 'Where the parties choose the law of a non-member State, that choice shall be without prejudice to the application of such mandatory rules of Community law as are applicable to the case.' tion. ${ }^{77}$ In my opinion, however, this does not mean that the articles of the Agency Directive themselves are to be considered as overriding mandatory rules. ${ }^{78}$ With regard to the application of the Directive's minimum harmonising provisions, there appears to be no discretionary power. Their mandatory application follows from the Directive's aim - to define a reasonable level of protection for commercial agents in the course of the creation of the single market. ${ }^{79}$ Nevertheless, another question concerns whether the national legislature may qualify its own legislation transposing Arts. 17 and 18 of the Directive as overriding mandatory rules and apply them instead of the law chosen by the parties. ${ }^{80}$ With regard to this issue, the CJEU refers to Art. 7 of the Rome Convention, according to which a certain margin of appreciation exists. In the event that the lex causae is the law of another Member State that has transposed the Directive in a correct manner, Member States are by no means obliged by the European legislature or the CJEU to qualify their own national provisions as overriding mandatory rules. In other words, there are limitations to the discretionary leeway for the Member States to qualify a national provision as an overriding mandatory provision in the sense of Art. $9,{ }^{81}$ but they are free not to qualify a national provision as such.

In my view, Ingmar should be interpreted as establishing a localising rule, which indicates the spatial reach of Arts. 17 and 18 of the Agency Directive and which prevails over the provisions of the Rome I Regulation pursuant to Art. 23 of the Regulation. It should be noted that Symeonides emphasises that localising rules are express provisions contained in statutes. ${ }^{82}$ However, the rule laid down by the CJEU in these judgements - namely, that Arts. 17 and 18 have to be applied where the situation is closely connected with the EU, especially where the commercial agent carries on his activity in a Member State, irrespective of the law chosen by the parties $^{83}$ - is unambiguous and can therefore be classed as an implicit localising rule. ${ }^{84}$

This interpretation is in line with the idea that overriding mandatory rules are rules of national law and that the question of whether a rule is adopted to protect an interest regarded as essential by the Member State concerned is to be decided on the national level, ${ }^{85}$ not by the Court of Justice. Ingmar shows that the Court - in

77. See Unamar, above n. 14, Rec. 41. Similar: Lüttringhaus, above n. 16 at 148 .

78. Contra: Kuipers and Vlek, above n. 31, at 201-02.

79. Unamar, above n. 14, Rec. 39 and 40.

80. Ibid., Rec. 41.

81. See above, Sections 2.1 and 2.2.

82. Symeonides, above n. 61, at 294

83. Ingmar, above n. 33, at 25.

84. See, in a similar sense, Stone, above n. 26, at 294 and W.H. Roth, 'Case C-381/98, Ingmar GB Ltd v. Eaton Leonard Technologies Inc.', Common Market Law Review 369, at 375-76 (2002). Also see M. Bogdan, 'The Rome I Regulation on the Law Applicable to Contractual Obligations and the Choice of Law by the Parties', Nederlands Internationaal Privaatrecht 407, at 410 (2009), stating that it possible to argue that restriction on party autonomy established in Ingmar falls within the scope of Art. 23 Rome I.

85. Unamar, above n. 14, Rec. 50 
the absence of an explicit localising rule - can determine the spatial reach of EU secondary legislation in international cases. Within that reach, the courts of a Member State will have to guarantee the level of protection provided by the European instrument, without having to establish whether the provision was adopted to protect an essential public interest for that Member State. ${ }^{86}$

\section{Relation to Minimum Harmonisation and Gold- Plating}

Another issue addressed in the Unamar judgement concerns deviations between laws of Member States transposing the Agency Directive as a result of the minimum harmonising nature of the Directive. In the previous section, it was argued that a Member State is obliged to guarantee the protection level provided by the Agency Directive in international situations in accordance with its localising rule. But what happens in an intra-EU situation, in which parties have chosen the law of a Member State to be applicable to their contract? It is clear that in such a situation - provided that the Member State has transposed the Directive in a correct way - the minimum protection provided by the Directive is ensured. However, the question arises as to whether the forum can still apply those provisions of its own law that exceed the level of protection given by the lex causae. This question is also relevant outside of the scope of the Agency Directive, since more Directives are based on the principle of minimum harmonisation. Until recently, the starting point of most consumerrelated Directives was that Member States could provide a higher level of protection. Although the Consumer Rights Directive is based on the principle of full harmonisation, the minimum harmonisation clauses of the previous consumer-related directives, replaced or amended by the new Directive, will still remain relevant for a considerable time, since the provisions of the latter apply only to contracts concluded after 13 June $2014 .^{87}$

With regard to minimum harmonisation, three types of discretionary leeway can be distinguished. ${ }^{88}$ First, the Member State can choose to gradually exceed the level of protection offered by the Directive - also known as 'gold-plating'. Second, the Member State can decide to extend the scope of application of the provisions of the Directive. Third, a Directive can provide several

86. It must be noted, however, that Unamar falls within the temporal scope of the Rome Convention, and it is not entirely clear whether the Court would decide the same under the Rome I Regulation, also taking into account the wording in Art. 3(4) (giving precedence only to European mandatory law over a choice of law for the law of non-Member State in purely intra-EU cases). However, in my opinion, Art. 3(4) does not overrule the Ingmar decision. If the Court had been of the view that Art. 3(4) Rome I did have an impact on Ingmar, it would probably have hinted at this in Unamar in an obiter dictum

87. See Art. 28(2) of the Consumer Rights Directive.

88. See Remien, above n. 39, at 339 . options from which the Member State can choose. In its Unamar judgment, the CJEU ruled with regard to the second type. When transposing the Agency Directive into Belgium law, the Belgium legislature chose to broaden the scope and to apply the provisions not only to agency contracts for the sale or purchase of goods but also to agency contracts for the operation of a shipping service. The Bulgarian legislature had expanded the scope equally. However, the level of protection afforded by Belgian law was higher than that of Bulgarian law, which was the law chosen by the parties. The Court of Justice concluded that the fact that the Agency Directive was correctly transposed in Bulgarian law did not automatically bar the Belgian court from qualifying its own law as an overriding mandatory provision in the sense of Art. 7 of the Rome Convention (Art. 9 of the Rome I Regulation).

It has been argued that the Unamar case does not provide information on how to deal with 'gold-plating' situations, since it concerns a type of agency contract that is not covered by the Agency Directive. Lüttringhaus claims that in cases that fall under the scope of the Directive and in which the Member State chooses to 'gradually transgress' the level of protection of the Directive, the national court should not be given the opportunity to apply a national provision on the basis of Art. 9(2) instead of the law of the Member State chosen by the parties to govern their contract. This would be against the principle of party autonomy, as well as in conflict with the ideal of decisional harmony within the EU. ${ }^{89}$ However, the CJEU does not seem to exempt national provisions that gradually exceed the level of minimum harmonisation of the Directive from the scope of Art. 9(2). After all, the Court distinguishes between 'extending the scope of a Directive' and 'choosing to make wider use of the discretion afforded by that Directive' but does not differentiate between their consequences. ${ }^{90}$ Therefore, in my opinion, the CJEU allows a national court to qualify a national rule - based on a minimum harmonisation Directive, but gradually transgressing the level of protection - as an overriding mandatory rule, if the legislature adopted it in order to protect an interest considered essential by that Member State. This is so, even if the applicable law is that of a Member State that has transposed the Directive correctly.

That is not to say that the CJEU's solution follows mandatorily from the provisions of the Rome Convention, Rome I Regulation, and EU law. A more limited interpretation would have been imaginable, since it concerns a rule with a European origin. For instance, the CJEU could also have placed some concrete limitations ${ }^{91}$ to the concept of 'overriding mandatory provisions' and decided that the application of gold-plated articles of the lex fori - rather than the lex causae of a Member State that has transposed the provisions of the Directive correct-

89. See Lüttringhaus, above n. 16, at 150 .

90. Unamar, above n. 14, Rec. 50.

91. See in a similar sense Roth (2009), above n. 39, at 869. 
ly - could not be justified and should be omitted. This interpretation would have been more in line with the principle of party autonomy and predictability of outcomes and would also further the harmonising effect of the Directive.

Although the CJEU insists that the concept of 'overriding mandatory rule' should be - in light of the principle of the freedom of contract - interpreted strictly, ${ }^{92}$ the Court actually opens space for judicial activism. If the Member State considers it of fundamental interest to provide extra protection of the law of the forum, it is to a great extent free to qualify its own gold-plated articles as overriding mandatory rules, which supersede the lex causae, even if that law guarantees the minimum level of protection. The court will, however, only apply its own provisions as overriding mandatory rules if they offer a higher level of protection than the law applicable to the contract; it is hard to imagine that the Belgian court in Unamar would have wanted to apply its national law if the agent had received more protection on the basis of Bulgarian law. Therefore, the CJEU de facto permits the adoption of a preferential law approach. However, there is a difference with the preferential law approach under Art. 9 of the Rome I Regulation on the one hand and with Arts. 6 and 8 on the other. According to the latter provisions, the court has a duty to apply the most protective rule, whereas with regard to Art. 9(2), the European legislature allows a court to apply an overriding mandatory rule of the lex fori instead of the lex causae..$^{93}$

\section{Conclusions}

Although the CJEU in Unamar ruled that the application of overriding mandatory rules restricts party autonomy and should therefore be interpreted narrowly, it also leaves considerable discretionary leeway to the Member States. The Court performs only a marginal review, from which one cannot expect too much. ${ }^{94}$ In fact, it opens the possibility for a national court to apply as overriding mandatory provisions national protective rules implementing an EU Directive but exceeding its minimum level of protection, even if the lex causae is the law of another Member State that has correctly transposed the Directive. From the point of view of predictability of outcomes and the goal of decisional harmony, this ruling is questionable. Moreover, Unamar arguably creates an imbalance between weaker party protection and the main cornerstone of the Rome I Regulation, namely, party autonomy.

This problem is partly solved by European Directives based on the principle of full harmonisation, such as the Consumer Rights Directive, since gold-plating is no longer allowed. However, the question remains as to whether national provisions transposing the Consumer
Rights Directive can be qualified as overriding mandatory rules if the chosen law is the law of a non-Member State. Considering the discretionary leeway given to the Member States in Unamar, it is possible that the CJEU's answer will be in the affirmative. However, the different nature of the Consumer Rights Directive in comparison to the Agency Directive, which was the point of focus in Unamar, should not be overlooked. The latter Directive leaves significant discretion to the Member States when they are transposing it to national legislation. This fact could still be seen as an argument to let Member States determine whether the national provisions based on the Directive should be qualified as overriding mandatory rules. Nevertheless, the Consumer Rights Directive does not leave a margin of appreciation with regard to its implementation into national law, which the European legislature justifies by stressing that it greatly increases legal certainty for consumers and businesses. ${ }^{95}$ As a consequence, there should also be no discretion as to whether the provisions, as transposed in national law, can be qualified as overriding mandatory rules.

The articles and recitals of the Consumer Rights Directive provide a strong argument that the answer to this question should be in the negative. After all, the Directive does not contain a localising rule, indicating that the level of protection given by the Directive should be guaranteed in the case of a choice of law for the law of a non-Member State. Instead, it refers explicitly to the Rome I Regulation to determine whether the consumer, in the event that the lex causae is the law of a nonMember State, retains the protection provided by the Directive. ${ }^{96}$ From this, one could deduce that the Directive's provisions were also not intended as overriding mandatory rules in the sense of Art. 9 Rome I. ${ }^{97}$ The result of this interpretation is that not all consumers residing in a Member State are entitled to the level of protection provided by the Consumer Rights Directive if the lex causae is the law of a non-Member State. However, consumers that fall within the scope of Art. 6 of the Rome I Regulation, and that are habitually resident in a Member State, remain fully protected. Moreover, Art. 3(4) of the Rome I Regulation guarantees protection to all consumers in purely intra-EU situations. By depriving national courts of their margin of appreciation to qualify their national rules with regard to transposing a full harmonisation Directive - such as the Consumer Rights Directive - as overriding mandatory provisions, the CJEU would strike a balance between party autonomy and the protection of weaker parties. At the same time, the Court would be fully adhering to the purpose of the Directive to ensure a high level of legal certainty.
95. See Directive 2011/83/EU, OJ 2011 L 304/64, Rec. 7.

96. See above, Section 4.1.

97. Plender and Wilderspin, above n. 13, at 261. 